\title{
IgE-dependent sensitization to tropho- and aeroallergens with regard to age, sex and birth season of children and adolescents living in the north-eastern region of Poland
}

\author{
Maciej Kaczmarski ${ }^{1}$, Dorota Citko ${ }^{2}$, Jolanta Wasilewska ${ }^{1,3}$ \\ ${ }^{1}$ Department of Paediatrics, Gastroenterology and Allergology, Medical University of Bialystok, Bialystok, Poland \\ ${ }^{2}$ Department of Statistics and Medical Informatics, Medical University of Bialystok, Bialystok, Poland \\ ${ }^{3}$ Centre for Paediatrics, Allergology, Psychodietetics and Treatment of Somatic Diseases in Children with Autism, Bialystok, Poland \\ Adv Dermatol Allergol 2020; XXXVII (6): 981-985 \\ DOI: https://doi.org/10.5114/ada.2020.102120
}

\begin{abstract}
Introduction: A small number of studies concern trophoallergens and aeroallergens sensitization in the developmental age population in Poland. Only a few studies describe the role of selected factors determining the frequency and type of IgE-dependent sensitization in this population.

Aim: To assess the rate of sensitization to chosen tropho- and aeroallergens in the group of sensitized patients living in the north-eastern region of Poland with regard to age, sex and birth season.

Material and methods: Skin prick testing (SPT) with selected food allergens (trophoallergens) and airborne allergens was used to evaluate the sensitization process of patients recruited to this study between 1998 and 2012. A positive result of sensitization was defined when the patient had at least one positive skin prick test with the allergen studied. The skin prick tests were done after written consent had been obtained from the parents.

Results: Significant results were as follows: sensitization was more common in boys (41.9\%) than in girls (35.7\%); the highest percentage of sensitized patients was observed in the group of children aged 13-18 years (45.0\%) as compared to the group of children up to 3 years old (the lowest 33.1\%). The highest percentage of sensitized patients was observed among children born during winter (41.3\%), the lowest among children born in autumn (36.8\%). Conclusions: The assessment of sensitization to chosen trophoallergens and airborne allergens should include the role of age, sex and birth season of the diagnosed patient.
\end{abstract}

Key words: IgE-sensitization, tropho/airborne allergens, age, sex, birth season.

\section{Introduction}

Epidemiological studies on allergic diseases in the human population, conducted in the last decades of the $20^{\text {th }}$ century, recorded an increasing trend in their prevalence in various regions of the world. Recent data suggest that this increase may now be levelling off. This trend includes both developmental age populations as well as adults [1-5].

Some studies have described the pattern of allergic sensitization during the first years of life, either in whole populations or in hospital-referred patients. They emphasize that sensitization to food allergens is prevalent in young children and is a factor that predicts the development of different allergic diseases [6-8]. In Poland, longterm data analysis concerning the sensitization process to trophoallergens and airborne allergens in the population of children and adolescents is not available. Therefore, we decided to perform a retrospective analysis of the scores of skin tests conducted in 1998-2012 in the population of children and adolescents in our region [9].

In the group of patients who underwent SPT as part of the current study, the percentage of those sensitized to at least one allergen was 39.0\%. Over the 14-year period, this percentage increased from $35.3 \%$ (1998) to $40.4 \%$ (2012). The analysis of the sensitization rate by allergen showed that the proportion of patients sensitized to trophoallergens increased two-fold from $10.5 \%$ in 1998 to $20.1 \%$ in 2012 , whereas the proportion of those sensitized to airborne allergens did not essentially change, accounting for 28.2\% in 1998 and 27.2\% in 2012 [9].

Address for correspondence: Prof. Maciej Kaczmarski, Department of Paediatrics, Gastroenterology and Allergology, Medical University of Bialystok, Bialystok, Poland, e-mail: maciej.kaczmarski@umb.edu.pl Received: 14.02 .2020 , accepted: 1.04 .2020$. 


\section{Aim}

The analysis takes into consideration the effect of age, sex and birth season on sensitization of the patients studied.

\section{Material and methods}

Of 6,577 children and adolescents who in 1998-2012 underwent SPT with tropho- and airborne allergens, 2,565 were sensitized to at least one allergen (irrespective of its type), which accounts for $39.0 \%$. In this group the sensitization process was analysed with regard to age, sex and sensitization season.

The characteristics of the study group and statistical analysis were described in detail in the first part of this publication [9].

\section{Study objective}

In the group of children and adolescents sensitized to chosen tropho- and aeroallergens, the effect of age, sex and birth season on the sensitization rate was assessed.

\section{Ethics}

The Bioethics Committee of the Medical University of Bialystok, Poland granted its approval for this study. Approval No. R-I-002/233/2009.

\section{Results}

Sensitization depending on sex, age, and season of birth in the children studied

The prevalence of sensitization, depending on sex, age and season at birth of the patient is presented in Table 1.

Table 1. Prevalence of sensitization in the period of 19982012 depending on sex, age and season at birth

\begin{tabular}{|c|c|c|c|c|}
\hline \multicolumn{2}{|c|}{ Characteristics } & \multirow{2}{*}{$\begin{array}{c}\begin{array}{c}\text { Number } \\
\text { of sensitized } \\
\text { patients }\end{array} \\
1110\end{array}$} & \multirow{2}{*}{$\begin{array}{c}\% \\
35.75\end{array}$} & \multirow{2}{*}{$\begin{array}{l}P \text {-value* } \\
<0.0001\end{array}$} \\
\hline Sex & Girls & & & \\
\hline & Boys & 1455 & 41.91 & \\
\hline \multirow[t]{4}{*}{ Age } & Up to 3 years & 651 & 33.05 & $<0.0001$ \\
\hline & $4-7$ years & 958 & 38.99 & \\
\hline & $8-12$ years & 548 & 44.02 & \\
\hline & $13-18$ years & 390 & 44.98 & \\
\hline \multirow{4}{*}{$\begin{array}{l}\text { Season } \\
\text { at birth }\end{array}$} & Spring & 693 & 40.08 & 0.0377 \\
\hline & Summer & 639 & 37.74 & \\
\hline & Autumn & 585 & 36.84 & \\
\hline & Winter & 626 & 41.29 & \\
\hline Total & & 2565 & 39.00 & \\
\hline
\end{tabular}

${ }^{*} \chi^{2}$ test of independence.
Sensitization was more common in boys (41.9\%) than in girls $(35.7 \%)(p<0.0001)$. A statistically significant relationship was found between the occurrence of sensitization and the age group $(p<0.0001)$. The highest percentage of sensitized individuals was observed in the group of children aged 13-18 years (45.0\%), the lowest in the group of children up to 3 years old (33.1\%). There was a statistically significant relationship between the occurrence of sensitization and birth season of the study participants $(p<0.038)$.

The percentage of sensitized patients was the highest among children born in winter (41.3\%), the lowest among children born in autumn (36.8\%).

\section{Sensitization to food and airborne allergens} depending on sex, age, and season at birth

There was a significant relationship between the occurrence of sensitization to food allergens and the age group $(p<0.0001)$ (Table 2$)$.

The highest percentage of children sensitized to a food allergen was observed in the youngest group of

Table 2. Prevalence of sensitization to food and airborne allergens in the years 1998-2012 depending on sex, age and season at birth

\begin{tabular}{|c|c|c|c|c|}
\hline \multicolumn{2}{|l|}{ Parameter } & $N$ & $\%$ & $P$-value* \\
\hline \multicolumn{5}{|c|}{ Food allergen sensitization: } \\
\hline \multirow[t]{2}{*}{ Sex } & Girls & 442 & 14.24 & \multirow[t]{2}{*}{0.0519} \\
\hline & Boys & 554 & 15.96 & \\
\hline \multirow[t]{4}{*}{ Age } & Up to 3 years & 426 & 21.62 & \multirow[t]{4}{*}{$<0.0001$} \\
\hline & $4-7$ years & 274 & 11.15 & \\
\hline & $8-12$ years & 170 & 13.65 & \\
\hline & 13-18 years & 119 & 13.73 & \\
\hline \multirow{4}{*}{$\begin{array}{l}\text { Season at } \\
\text { birth }\end{array}$} & Spring & 253 & 14.63 & \multirow[t]{4}{*}{0.0685} \\
\hline & Summer & 250 & 14.77 & \\
\hline & Autumn & 223 & 14.04 & \\
\hline & Winter & 261 & 17.22 & \\
\hline \multicolumn{5}{|c|}{ Airborne allergen sensitization: } \\
\hline \multirow[t]{2}{*}{ Sex } & Girls & 860 & 27.70 & \multirow[t]{2}{*}{$<0.0001$} \\
\hline & Boys & 1170 & 33.70 & \\
\hline \multirow[t]{4}{*}{ Age } & Up to 3 years & 314 & 15.94 & \multirow[t]{4}{*}{$<0.0001$} \\
\hline & $4-7$ years & 852 & 34.68 & \\
\hline & $8-12$ years & 498 & 40.00 & \\
\hline & 13-18 years & 354 & 40.83 & \\
\hline \multirow{4}{*}{$\begin{array}{l}\text { Season at } \\
\text { birth }\end{array}$} & Spring & 567 & 32.79 & \multirow[t]{4}{*}{0.0255} \\
\hline & Summer & 500 & 29.53 & \\
\hline & Autumn & 457 & 28.78 & \\
\hline & Winter & 491 & 32.00 & \\
\hline
\end{tabular}

${ }^{*} \chi^{2}$ test of independence. 
children aged up to 3 years (21.6\%). No significant relationship was noted between the occurrence of sensitization to a food allergen and sex and the season at birth. Boys were significantly more often sensitized to an airborne allergen (33.7\%) than girls $(27.7 \%)(p<0.0001)$.

There was a significant relationship between the occurrence of sensitization to airborne allergens and the age group ( $p<0.0001)$. The oldest children - from 13 to 18 years $(40.8 \%)$ - were most often sensitized to airborne allergens and the youngest children aged up to 3 years (15.9\%) - the least often. There was a significant relationship between the occurrence of hypersensitivity to an airborne allergen and the season at birth $(p<0.03)$. The lowest percentage of patients with a hypersensitivity to an airborne allergen was observed in the group of children born in autumn (28.8\%), the highest in the group of children born in spring (32.8\%) and in winter (32.0\%).

\section{Sensitization to both food and airborne allergens}

After isolating the group of children who were sensitized to both food and airborne allergens, a significantly higher percentage of hypersensitivity to airborne allergens was observed among boys (7.7\%) than in girls $(6.2 \%)(p<0.017)$ (Table 3).

There was a significant relationship between the occurrence of sensitization simultaneously to airborne allergens and age group $(p<0.0001)$. The highest percentage of children sensitized to both food and airborne allergens was observed in the groups of children aged from 8 to 12 years (9.6\%) and from 13 to 18 years (9.6\%), whereas the lowest in the group of children aged up to 3 years (4.5\%). No significant relationship was noted between the occurrence of sensitization simultaneously to food and airborne allergens and sex and the season at birth.

A significant relationship was found between the occurrence of sensitization only to food allergens and the age group $(p<0.0001)$. The highest percentage of sensitization to food allergens only was observed in the group of youngest children aged up to 3 years (17.2\%).

In the remaining age groups this percentage was at a level of approximately 4.0\%. There was no relationship between the occurrence of hypersensitivity only to food allergens and sex and the season at birth.

The rate of sensitization only to airborne allergens was significantly higher among boys (26.0\%) than girls $(21.5 \%)(p<0.0001)$. A significant relationship was found between sensitization to airborne allergens and the age group ( $p<0.0001)$. The highest percentage of sensitization only to airborne allergens was observed in the group of the oldest children aged 13 to 18 years (31.3\%) and the lowest in the youngest children up to 3 years of age (11.5\%). There was no relationship between the occurrence of sensitization only to airborne allergens and the season at birth.

\section{Discussion}

Epidemiological data of the last three to four decades indicate that the prevalence of allergic diseases among residents of countries with high economic and hygienic

Table 3. Occurrence of sensitizations to food and airborne allergens in the period from 1998 to 2012 depending on sex, age, and season at birth of the study participants, with isolation of the group of children who were sensitized to both food and airborne allergens

\begin{tabular}{|c|c|c|c|c|}
\hline \multicolumn{2}{|l|}{ Parameter } & $N$ & $\%$ & $P$-value* \\
\hline \multicolumn{5}{|c|}{ Sensitizations to food allergens only: } \\
\hline \multirow[t]{2}{*}{ Sex } & Girls & 250 & 8.05 & \multirow[t]{2}{*}{0.7510} \\
\hline & Boys & 287 & 8.27 & \\
\hline \multirow[t]{4}{*}{ Age } & Up to 3 years & 338 & 17.16 & \multirow[t]{4}{*}{$<0.0001$} \\
\hline & $4-7$ years & 107 & 4.35 & \\
\hline & $8-12$ years & 50 & 4.02 & \\
\hline & $13-18$ years & 36 & 4.15 & \\
\hline \multirow{4}{*}{$\begin{array}{l}\text { Season } \\
\text { at } \\
\text { birth }\end{array}$} & Spring & 126 & 7.29 & \multirow[t]{4}{*}{0.3712} \\
\hline & Summer & 140 & 8.27 & \\
\hline & Autumn & 128 & 8.06 & \\
\hline & Winter & 136 & 8.97 & \\
\hline
\end{tabular}

Sensitizations to airborne allergens only:

\begin{tabular}{lllll}
\hline \multirow{2}{*}{ Sex } & Girls & 668 & 21.51 & \multirow{2}{*}{$<0.0001$} \\
\cline { 2 - 4 } & Boys & 903 & 26.01 & \\
\hline \multirow{2}{*}{ Age } & Up to 3 years & 226 & 11.47 & \multirow{2}{*}{$<0.0001$} \\
\cline { 2 - 4 } & 4-7 years & 685 & 27.88 & \\
\cline { 2 - 4 } & 8-12 years & 378 & 30.36 & \\
\cline { 2 - 4 } & 13-18 years & 271 & 31.26 & \\
\hline \multirow{2}{*}{$\begin{array}{l}\text { Season } \\
\text { at } \\
\text { birth }\end{array}$} & Spring & 440 & 25.45 & \multirow{2}{*}{0.2522} \\
\cline { 2 - 4 } & Summer & 390 & 23.04 & \\
\cline { 2 - 4 } & Autumn & 362 & 22.80 & \\
\cline { 2 - 4 } & Winter & 366 & 24.14 &
\end{tabular}

Sensitization to both food and airborne allergens:

\begin{tabular}{|c|c|c|c|c|}
\hline \multirow[t]{2}{*}{ Sex } & Girls & 192 & 6.18 & \multirow[t]{2}{*}{0.0167} \\
\hline & Boys & 267 & 7.69 & \\
\hline \multirow[t]{4}{*}{ Age } & Up to 3 years & 88 & 4.47 & \multirow[t]{4}{*}{$<0.0001$} \\
\hline & $4-7$ years & 167 & 6.80 & \\
\hline & $8-12$ years & 120 & 9.64 & \\
\hline & $13-18$ years & 83 & 9.57 & \\
\hline \multirow{4}{*}{$\begin{array}{l}\text { Season } \\
\text { at } \\
\text { birth }\end{array}$} & Spring & 127 & 7.34 & \multirow[t]{4}{*}{0.0685} \\
\hline & Summer & 110 & 6.49 & \\
\hline & Autumn & 95 & 5.98 & \\
\hline & Winter & 125 & 8.24 & \\
\hline
\end{tabular}

${ }^{*} \chi^{2}$ test of independence. 
standards has been systematically increasing. This trend includes both developmental age populations as well as adults [1-5]. According to the available data, the number of people with allergic hypersensitivity in some regions of the USA doubles every 10 years. Sensitization to selected environmental allergens affects about $40 \%$ of the population. The analysis contained in the White Book of Allergy suggests that with such a growth rate, the number of people sensitized in 2020 will be higher than that of healthy people $[10,11]$.

Our retrospective research involving 2,565 patients showed interesting relationships of sensitizations with age, sex and season at birth. Sensitizations were more common in boys (41.9\%) than in girls (35.7\%), the difference being statistically significant. A statistically significant relationship was also found between the occurrence of sensitization and the age group. The highest percentage of sensitized individuals was observed in the group of children aged $13-18$ years (45.0\%), the lowest in the group of children up to 3 years old (33.1\%). This research showed that the birth season of the children surveyed had a significant impact on the sensitizing process. The highest percentage of sensitized patients was noted among children born during winter (41.3\%), the lowest among those born in autumn (36.8\%).

Previous epidemiological studies considering the effects of age, sex and season at birth on the allergic sensitization process in children are rather scarce [5, 11-13].

Govaere et al. investigated the prevalence of allergic symptoms and their associations with sensitization in an unselected population of Flemish children, with the mean age of 9.3 years, living in the city and the surrounding area. Skin prick testing with the most common aeroallergens was performed. Among 2,021 children included in that study, 1,538 (76.1\%) had negative skin prick tests and 483 (23.9\%) had at least one positive skin prick test. In that group, $60.6 \%$ of those sensitized were boys, and $39.4 \%$ girls. The percentage of allergic patients depending on age was as follows: 3.4 to 6 years $-11.8 \%$; 6 to 8 years $-8.1 \%$; 8 to 10 years $-12.8 \%$; 10 to 12 years $41.0 \%$; 12 to 14.8 years $-26.3 \%$ [14].

Norrman and Falth-Magnusson, who analysed the SPT results of 5,908 children (mean age: 6.4 years) showed that $46.0 \%$ of them had a positive test at least to one allergen. There were slightly more boys (55.0\%) than girls (45.0\%) in the study group. The total percentage of positive skin prick tests to various food, pollen and animal allergens was $18.0 \%$, and was identical to that in the age group of $0-2$ years. The highest percentage of sensitizations (22.0\%) was noted in the age group of 13-18 years [15].

The season at birth was reported to be a risk factor for food allergy but the mechanisms by which it acts are unknown [14].

The relationship between birth season and food allergy was studied by Keet et al. in two large groups: 5,862 children from the National Health and Nutrition Examination Survey (NHANES) and 1,514 children with food allergy from Johns Hopkins Pediatric Allergy Clinic (JHPAC). Autumn birth was more common among food allergic subjects in both NHANES $(O R=1.91)$ and JHPAC $(O R=$ 1.31) groups.

Ethnicity of the studied children (Caucasian, OR = 2.34 vs. non-Caucasian, $O R=1.19$ ) and skin barrier dysfunction (subjects with a history of eczema) constituted a group of increased risk of sensitization to food allergens. In the Caucasian ethnic group, the highest percentage of allergic patients was recorded in September and November. The authors observed greater predisposition to sensitization in relation to the season of birth (autumn) or skin condition (damaged), associating it with a seasonal variation in the vitamin D level $[15,16]$.

Among $86.2 \%$ of sensitized patients to at least one allergen, Quoix et al. found a significant difference in the month of birth distribution for patients (especially among women) with positive skin tests to grass pollen, with a high rate of birth from January to May [17]. For the whole sensitized population, the birth rate tended to be low in December, except for the cat and dog sensitized. According to these authors, their study confirmed the well-known seasonal peak of births in the first 5 months of the year for grass pollen sensitized patients. The same comparison by sex showed no significant difference between patients sensitized and the reference population.

Garcia et al. studied 44 infants of both sexes, aged less than 12 months, who attended the dermatology department with symptoms suggesting atopic dermatitis. The aim of analysis was the clinical relevance of the IgEdependent sensitizations in this disease. The relationship was studied using SPT and measurement of specific serum IgE (s-IgE). Of the 44 patients studied, sensitization to foods was detected in 27 (61.0\%), and the most frequent sensitization observed was to egg [6].

De Benedictis et al. analysed study results concerning lgE-dependent sensitization of infants with atopic dermatitis from 12 countries [7]. A total of 2,222 children were screened, of which 2,096 (mean age: 17.6 months; 57.1\% male: $92.0 \%$ Caucasian) were included in data analysis. Atopy was defined as a presence of at least one specific lgE measurement $>0.35 \mathrm{kU}_{\mathrm{A}} / \mathrm{l}$ and/or total IgE measurement $>30.0 \mathrm{kU} / \mathrm{l}$. The analysis showed that $44.5 \%$ were not sensitized; $18.7 \%$ were monosensitized and $36.8 \%$ were polysensitized with specific lgE $\geq$ class 1 . There was a wide variation in the sensitization rate to food between countries. Sensitization to egg white predominated in each country and was particularly common in Australia (54.0\%), Italy and the UK (53.0\%). The highest sensitization rate to cow milk was found in Italy (48\%). The prevalence of sensitization to food allergens was particularly low in Belgium (egg 23.0, milk 14.0\%) and Poland (egg 27.0\%, cow milk 18.0\%). A large varia- 
tion in the sensitization rate to airborne allergens was also observed between the countries studied [7].

Of the 501 children from the DARC cohort, who had at least one s-IgE test performed between 3 and 72 months of age -146 (29.1\%) had more than one positive IgE, to egg, milk, peanut or fish [8].

\section{Conclusions}

The retrospective research concerning the prevalence of sensitization in the population of children and adolescents in north-eastern Poland in 1998-2012, extends the knowledge of the process of IgE-dependent sensitization in this age population in our country. Our study results may serve as reference to that type of research conducted in other countries. They also indicate an essential effect of such factors as age, sex and birth season on the rate of sensitization to chosen tropho- and airborne allergens in the population studied.

\section{Acknowledgments}

This project was funded by the Medical University of Bialystok, Poland. The Bioethics Committee Approval No. R-I-002/233/2009.

Maciej Kaczmarski is professor emeritus, head of the department in the years 1990-2014.

\section{Conflict of interest}

The authors declare no conflict of interest.

\section{References}

1. Isolauri E, Hurre A, Salminen S, Impivaara O. The allergy epidemic extends beyond the past few decades. Clin Exp Allergy 2004; 34: 1007-10.

2. Prescott SL, Pawankar R, Allen KJ, et al. A global survey of changing patterns of food allergy burden in children. WAO J 2013; 6: 1-12.

3. Novak D, Suppli UC, von Mutius E. Asthma and atopy; has peak prevalence been reached? Eur Respir J 2004; 23: 359-60.

4. Asher MI, Montefort S, Björksten B, et al. Worldwide time trends in the prevalence of symptoms of asthma, allergic rhinoconjunctivitis, and eczema in childhood: ISAAC Phases One and Three repeat multicountry cross-sectional surveys. Lancet 2006; 368: 733-43.

5. Papadopoulos NG, Agache J, Bavbek S, et al. Research needs in allergy: an EAACI position paper in collaboration with EFA. Clin Transl Allergy 2012; 2: 21.

6. Garcia C, El-Qutob D, Martorell A, et al. Sensitization in early age to food allergens in children with atopic dermatitis. Allergol Immunopathol 2007; 35: 15-22.

7. de Benedictis FM, Francheschini F, Hill D, et al. The allergic sensitization in infants with atopic eczema from different countries. Allergy 2009; 65: 295-303.

8. Eller E, Kjaer HF, Host A, et al. Food allergy and food sensitization in early childhood; results from the DARC cohort. Allergy 2009; 64: 1023-9.
9. Kaczmarski M, Citko D, Wasilewska J. The prevalence of IgEdependent sensitizations to selected trophoallergens and airborne allergens in the population of children and adolescents of the north-eastern region of Poland. Adv Dermatol Allergol. Adv Dermatol Allergol 2020; 37: 790-5.

10. Pawankar R, Canonica GW, Holgate ST, Lockey RF (eds.). World Allergy Organization (WAO) White Book on Allergy: WAO 2011.

11. Leynaert B, Neukirch C, Kony S, et al. Association between asthma and rhinitis according to atopic sensitization in a population-based study. J Allergy Clin Immunol 2004; 113: 86-93.

12. Burney PG, Potts J, Kummeling I, et al. The prevalence and distribution of food sensitization in European adults. Allergy 2014; 69: 365-71.

13. Dor-Wojnarowska A, Liebhart J, Miecielica JB, et al. The impact of sex and age on the prevalence of clinically relevant sensitization and asymptomatic sensitization in the general population. Arch Immunol Ther Exp (Warsz) 2017; 65: 253-261.

14. Govaere E, Van Gysel D, Verhamme K, et al. The association of allergic symptoms with sensitization to inhalant allergens in childhood. Pediatr Allergy Immunol 2009; 20: 448-57.

15. Norrman G, Falth-Magnusson K. Adverse reactions to skin prick testing in children - prevalence and possible risk factors. Pediatr Allergu Immunol 2009; 20: 273-8.

16. Keet CA, Matsui EC, Savage JH, et al. Potential mechanisms for the association between fall birth and food allergy. Allergy 2012; 67: 775-82.

17. Quoix E, Bessot JC, Kopferschmitt-Kubler MC, et al. Positive skin tests to aero-allergens and month of birth. Allergy 1988; 43: 127-31. 